\title{
A Tale of Sound and Fury Signifying Everything: Argentine Tango Dance Films as Complex Self-Reflexive Creation
}

\author{
Fátima Chinita \\ Lisbon Polytechnic Institute (Portugal) \\ E-mail: chinita.estc@gmail.com
}

\begin{abstract}
This article equates the multidimensional artistic form of Argentine tango (dance, music and song) with the innately hybrid form of film. It compares Argentine tango culture to the height of French cinephilia in the 1950s Paris, France, arguing that they are both passionate, erotic and nostalgic ways of life. In Carlos Saura's Tango (1998) and Sally Potter's The Tango Lesson (1997), the intertwining of the related skills of tango practice and filmmaking are an audio-visual treat for the senses and a cognitive challenge for the mind. Their self-reflexivity promotes excess and the result is a highly expressive and complex form. They evince a cross-fertilization of reality and fiction, of art and life, typical of a perfect mise en abyme as described by Christian Metz. These films are also art musicals, although they depart from the Hollywood musical conventions. Yet, one cannot speak in their case of intermedia reflexivity, according to Petr Szczepanik's definition, because both of them retain their qualities in a symbiotic relationship of likeness that highlights their mutual aura.
\end{abstract}

Keywords: Argentine tango, meta-cinema, self-reflexivity, hybridity, intermediality, cinephilia.

\section{Introduction: To Begin with, or La Salida}

Argentine tango is a threefold art made up of dance, song and a purely instrumental form (Bloomsbury Encyclopedia 2014, 826). The authors of Tracing Tangueros consider it to be a "multidimensional" artistic form combining dance, music and poetry: "just as the dance strikes a pose in a sensual embrace, the music cries with the woeful sounds of the bandonéon, and the poetry laments a bygone time" (Link and Wendland 2016, 1). García Brunelli goes farther in that he does not limit the poetry to the lyrics, considering it instead part of a full-fledged cultural legacy: "poetry is the product of a wonderful poetic quality and an appealing 
cultural density" (2015, 4, my translation). In fact, on the $30^{\text {th }}$ of September 2009, UNESCO provided grounds for these and other related arguments when it declared "tango" (music, dance, and song) part of the Intangible Cultural Heritage of Humanity and charged all professionals dealing with it, in one way or another, with the responsibility of protecting and preserving tango culture. ${ }^{1}$

Because it is multidimensional, most of the times, tango is also interdisciplinary. There cannot be tango dance without tango music, with or without lyrics. OmarGarcía Brunelli claims that when tango is meant to be danced, a special communication between musicians and dancers is established $(2015,26)$. Furthermore, Brandon Olszewski argues that dancing to the music (i.e. in synch with it) while adjusting to one's partner's highly improvisational movements contributes to Argentine tango's renowned complexity $(2008,72) .^{2}$ Even Ástor Piazzolla's Tango Nuevo, a type of intellectual instrumental music not meant to be danced to, can actually be danced to, as attested by Sally Potter's and Pablo Verón's rendition of Libertango in the film The Tango Lesson (1997). Indeed, the Bloomsbury Encyclopedia claims that "any tango can be danced, whether it is a song or an instrumental piece” $(2014,826)$. In what follows, I approach tango dance from this interdisciplinary perspective, focusing on two case studies from the 1990s: Tango (1998, written and directed by Carlos Saura, original music and orchestration by Lalo Schifrin, a co-production between Spain and Argentina) and The Tango Lesson (1997, written and directed by Sally Potter, music by Fred Firth and Sally Potter, a co-production between UK, France, Argentina, Germany and the Netherlands).

I follow an intermedial purpose: to conflate two different art forms - dance and cinema, and more specifically the already hybrid subcategories of tango and metafilms - in order to highlight a discourse on inter-art creativity. According to Petr Szczepanik (2002, 29): "reflexivity constitutes a fundamental feature of all kinds of intermediality." Saura's Tango and Potter's The Tango Lesson are both metafilms and which, for the purpose of this article, I consider to be films about films, in which the auteur, consciously and recurrently, portrays cinema in the act of being made or watched. ${ }^{3}$ According to Lucien Dällenbach (1977), all films that portray the

1 See the full text here: https://ich.unesco.org/en/RL/tango-00258. Last accessed 15. 07. 2021.

2 Unlike ballroom tango, Argentine tango - from which the former derives - has no choreography whatsoever when practiced socially. Although there is a set of key steps, the pairs simply improvise upon them.

3 I do not restrict this filmic category to the classical products that merely depict the film industry and/or the lives of those involved (Hollywood-on-Hollywood Films); neither do I exclusively regard it as the modernist variety defended by William C. Siska (1979). What I consider to be meta-cinema exists at the exact intersection of the former two aspects: films about the activity of filmmaking that are also (self-) reflexive. For the sake of simplicity, I consider meta-films to 
agents, the process and the context of production and/or reception can be said to be enunciative mise en abymes (in English: "mirror images"). The more self-reflexive a film is, the more powerful and complex the mirroring becomes. In my two case studies, self-reflexivity directly serves the film's theme together with the film's specific subject. It is my contention that in these two films, the art and practice of filmmaking directly reflect tango's musical and choreographic complexity (as well as its philosophy of life), binding the two art forms closely together.

\section{For the Sake of Passion}

Cinema and Argentine tango have much in common and it is rather surprising that, to my knowledge, the connection has never been made before. Both are art forms and passionate institutionalized cultures. More importantly, there is something inexplicably enticing about Argentine tango and cinema alike. Murray Pfeffer, in his brief history of tango, observes: "El tango no es en los pies. Es en el corazón" ["Tango dance resides not in the feet, but rather in the heart"]. ${ }^{4}$ For all moviegoers, and especially confessed cinephiles, that diehard category of viewers, cinema is also an intense experience.

Robert Farris Thompson asserts that "Tango is the art history of love. It is the dance that teaches the world to love and to live in the idiom of Buenos Aires" (2005, 275). Brandon Olszewski (2008) claims that under normal circumstances, there is a kinetic relationship between two people who dance in an embrace on a dance-floor in synch to the music. Sometimes that connection, termed by him cuerpo de baile, is so strong that it conveys the impression of the partners merging into a single entity. Sadly, that connection must come to an end. Kathy Davis adds: "it is this transitory quality that forms an essential feature of tango passion. Connection is not only about people coming together. It is also about leaving one another and longing to return another time, for another dance, again and again and again" $(2015,12)$. Director Sally Potter states that "there is something about [tango] that really inspires obsession, even addiction” (Béhar 1997). Kathy Davis, a feminist academic who dances the tango, concurs with her opinion. She considers it a "bodily activity that is intensely pleasurable, addictively desired, but also unsettling, disruptive" $(2015,3)$.

be films that belong to the overall category of meta-cinema, and not films that reveal their own construction (as argued by Christian Metz 1991).

4 http://www.trio.garufa.com/tango-history.html. Last accessed 15. 07. 2021. All translations in square brackets are mine. 
As historically noted by Antoine de Baecque (2003, 9), the same was felt in the height of cinephilia in the 1950s Paris, France, by the various "tribes" of specialized filmgoers, whose lives were entirely organized around films. They, too, were intent on establishing a personal and intense relationship with the films they watched, mesmerized by the images and the filmic moment, as explained by one of the film-buff protagonists of Bernardo Bertolucci's film The Dreamers (2003): "I was one of the insatiables. The ones you would always find sitting closest to the screen. [...] we wanted to receive the images first, when they were still new, still fresh, before they cleared the hurdles of the rows behind us, before they had been relayed back from row to row, spectator to spectator, into worn out second-hand the size of a postage stamp to return to the projectionist cabin."

Argentine tango and cinema are both cults and ways of life. The "Tango culture" - originally referring to the practices and customs of the early disadvantaged "porteños," ${ }^{5}$ mostly European immigrants from Italy and Spain, peasants from the Argentinian hinterland (the gauchos) and descendants of liberated African slaves - meant a dress code, a certain bodily communication, a social stratum and specific sites. ${ }^{6}$ Today, it is still an all-consuming pastime for many Buenos Aires residents, who dance through the night at neighbourhood dance clubs known as milongas, where tourists hardly ever enter. As for the Parisian cinephilia of the 1950s, it was in the beginning, according to de Baecque $(2003,19)$, a "counterculture," an underground community turned inwards and confined to its own rituals, bound together by a complicity of taste, a practice of writing and talking incessantly about films as well as undertaking a fetishistic smuggling of directors' filmographies and screenplays (de Baecque 2003, 20-21). There was even a film theatre of choice for each group of cinephiles.

The Argentine tango is a dramatic dance, full of emotion expressed from inside out, and deeply erotic by nature. The dancers are suffused with emotion, but do not express it outwardly, dancing with blank expressions (cara fea) and in absolute silence. Argentine tango is a dance of solely corporeal communication,

$5 \quad$ Residents of Buenos Aires. They got their name from the port area of the Río de la Plata.

6 The "compadrito" a ruffian, thief and pimp, wore a brimmed hat thrown over one eye, a white handkerchief tied around his neck, a short tight coat, baggy trousers, a knife at his side, and had a waddling gait. Most commentators argue that tango was originally danced at poor and/ or ill-reputed venues: brothels, academias (where locals danced with in-house dancers), peringundíns (taverns in which both couples and single men danced), conventillos (miserable and highly populated tenement buildings for immigrants), and the street (where compadritos exhibited their skills, often challenging one another) (Cámara de Landa 2003, 98). For a detailed description of the tango culture upon its inception, see Jorge Luis Borges's four conferences on tango (2018). 
performed in close embrace (i.e. chest-to-chest, with joined bodies moving on their axis) and in which only the legs are free for downward extensions and other manoeuvres. R. F. Thompson claims that "if tango were only sex the art would evaporate. [...] But all the best dancers combine art and sensuousness, exploring the consequences" (2005, 276). Some movements - the boleo (a rapid kick backwards), la metida (a leg quickly introduced between one's partner's legs), the quebrada (a lateral torsion of the hips), and the ocho (in which the woman twirls in front of the man, imitating the figure eight) - are brisk but exciting movements, reinforcing the syncopated rhythm of the music and its intrinsic fluctuations, caused by marcato (playing some notes with more strength than others), and arrastre (e.g. a stroke that changes the speed), among others. Link and Wendland observe that "Arrastre further accentuates tango accompaniment by creating an aural impression of yearning and striving." $(2016,30)$.

Similarly, cinema as lifestyle in the Paris of the 1950s was imbued with erotomania. Both for the "Young Turks," a group of radical young writers for Cahiers du cinéma, and for the older critics of specialized film magazines, love for women was inseparable from their love for films. According to de Baecque (2003, 269), the younger generation of cinephiles had their own sentimental education in the film theatres. Nonetheless, in my opinion, it is the experience of cinema as a whole irrespective of the films' contents that matters most for the comparison that I am trying to establish here. Indeed, Christian Metz, in his book The Imaginary Signifier (1980, 75-76), describes the Seventh Art as a voyeuristic activity, one in which the film projected on the screen serves as an exhibitionist to the spectators' desire to watch. Via the cinematic institution, a dual consensual relationship is thus metaphorically established between film watcher and film watched, in which the latter, especially in fictional and classically structured films, captivates the spectator in a darkened immersive atmosphere, which is in itself erotic inasmuch as the film is offered to the viewer through the filmic apparatus. Everything in the film (i.e. characters, actions, camera placement and mise en scène) is transparent, as if the viewer did not exist. Moreover, due to the inherent conditions of production and reception, film viewers are never present in the act of filmmaking, nor are they on the screen upon which the film is being shown. Thus, according to Metz, films are always in an inaccessible, "primordial somewhere, highly desirable (= forever unobtainable) in a scene of absence" (1980). The impossibility of fusion transforms the spectators' longing into a perpetual condition of cinephilia. Consequently, sacred eroticism $\underline{\text { is }}$ attained through sublimation: cinephilia, the exacerbated love for cinema, consists in 
placing the film at an altogether different (and higher) level of existence from where it can be worshipped from afar. This much is granted by Sally Potter about tango in The Tango Lesson, in which, at some point, she makes the dancer Pablo Verón say: “Je crois qu'il faut mieux sublimer l'attirance qu'on a l'un pour l'autre dans le travail" ["I think it's best to sublimate the attraction we have for each other and direct it towards our work together"] (Grunes 2007).

Thomas Elsaesser contends that in all types of cinephilia, but especially that of the first generation (in the 1950s Paris), the transience of the cinematic experience and the sense that it is unrecoverable always induces nostalgia, a feeling of anxiety and mourning $(2005,33)$. However, Jenna $\mathrm{Ng}$ asserts that cinephilia is infused with much more: death, nostalgia, regret, bleakness, longing, hopelessness, reminiscence $(2005,66)$. In short, all what Argentine tango evokes. The famous Argentinian lyricist Enrique Santos Discépolo contends that "El tango es un pensamiento triste que se baila" ["Tango is a sad thought expressed through dance"] (quoted in Link and Wendland 2016, 11). Throughout Argentine tango's history, its lyrics have been filled with all types of misery and misfortune. From the deceit, abandonment, frustration and lost love contained in the first tango song - Mi noche triste (1917, music by Samuel Catriosta and lyrics by Pascual Contursi) - to the social uprooting of the immigrants, their disappointments, nostalgia for the homelands left behind as well as the fatalities and unhappy endings of the 1920s and 1930s, tango song has been "the exaltation of failure" (García Brunelli, 2015, 24, quoting Rosalba Campra, my translation).

\section{Labyrinthine Steps}

Beyond art form practices, reception models, and genre conventions; the analogy between Argentine tango and meta-cinema may be carried right into the story and the way it is conveyed. Both Saura's Tango and Potter's The Tango Lesson are asserted discourses on creation, representing the absorbing nature of filmmaking and the effort it demands from its principal maker, the art house director as leader of the project, just as the best tango dancers obsess about practicing their moves and attaining excellence.

Saura's Tango begins in deadlock. The protagonist, the director Mario (played by Miguel Ángel Solá), has been left by his female life partner, the dancer Laura (played by Cecília Narova), and remains in sentimental denial, despite the fact that she is now living with another man. Eventually, by working on his tango project - a musical with dance, song and intradiegetic film projection - he is 
empowered again, and becomes able to lead his own life as he leads the project with stern resolution (even going against the investors' recommendations). At one point he observes: "Oh, inspiration where are you? And what is inspiration if not work, work, work?" ${ }^{7}$ His new take on life involves courting a young dancer, Elena (played by Mía Maestro), who befriends a mobster. Mario, therefore, plays with fire and the exhilaration of danger.

In Potter's The Tango Lesson, the protagonist, Sally (played by the director, Sally Potter, herself) chooses to abandon a filmic project on fashion models that she was preparing. She does this because she cannot gain the investors' trust to make it exactly as she wanted, opting for a more personal project on tango instead. It is quite relevant that the creative character in her abandoned film is a disabled male stylist (quite literally without legs), whereas the protagonist of her own dance film is a woman who can stand - and dance - on her own two feet. The entire Tango Lesson, thus, depicts the struggle for power of a woman in a man's world, or more precisely, how others end up socially and emotionally accepting her already existent power. Tango serves as a metaphor both for the commitment that relationships require and the involvement and "trust" that filmmaking calls for. Empowerment, of the right kind, comes only through sacrifices and suffering. In fact, upon finding out that she dances the tango, a taxi driver in Buenos Aires ventures that she must have lived and suffered in order to be able to understand his country's tangos.

Nevertheless, in both Saura's Tango and Potter's The Tango Lesson, tango is not only the catalyst of creation; it is the very means by which the creation comes to exist. Indeed, these films convey their message by intertwining the related skills of tango practice and filmmaking in an audio-visual treat for the senses and a cognitive challenge for the mind. Both are hybrid and highly complex, as befits an approach to the Argentine tango, unanimously considered by theorists and practitioners to be the pinnacle of creativity and inspiration in traditional dances, thereby replicating the complexity contained in the instrumental form. ${ }^{8}$ The bandonéon - a type of concertina, tango's most iconic musical instrument with its predominant sound - is considered by Link and Wendland "a devilishly difficult instrument to play" $(2016,26),{ }^{9}$ just as the dance is extremely "complex

$7 \quad$ All quotations from the films are taken from the translated DVD versions I consulted.

8 The Bloomsbury Encyclopedia, for example, states that "tango has endured as one of the bestknown and complex popular music forms (instrumental, sung or danced) in the world" $(2014,839)$.

$9 \quad$ The bandonéon has 71 buttons in total (38 on the right side and 33 on the left side). The musical notes are organized according to pitch and change entirely depending on whether the bellows are opened or closed, which effectively doubles their number (Link and Wendland 2016, 26). 
in transitions and mood shifts" (Thompson 2005, 170). ${ }^{10}$ Both Saura's Tango and Potter's The Tango Lesson are actually more than just films on filmmaking (i.e. reflexive films) in that they do away with the transparency of classical cinema. In them, the disclosure of the apparatus and other self-reflexive devices function as an acknowledgement of the constructed nature of cinema, furthering the relationship with tango, which since its inception at the end of the nineteenthcentury has always been a musical genre replete with ornamental excesses that cause the rhythm to move upbeat and downbeat and the music to change tempo.

The concept of cinematic excess, as developed by Kristin Thompson (1977), can be invoked here to emphasize the relationship between these two art forms, especially when applied to the cases in question. According to Thompson (1977, 55), "excess" occurs when the form overcomes the narrative, which thus seems to be devoid of real motivation. Form shines through colour, textures, use of decor, composition, musical accompaniment, or any other filmic aspect that is rendered strange in a particular context when there is no narrative explanation for it. Kristin Thompson comments that certain film styles (i.e. personal recurrent directorial choices) can use some elements in a highly exaggerated manner, possibly leading the spectator into an awareness of excess $(1977,60)$. Although it is a general film philosophy rather than a style, self-reflexivity promotes excess and, in the case of the two tango dance films under scrutiny here, the result is highly expressive and complex. In these films, ornaments exist for sensorial reasons instead of narrative ones; rather than being a mere flourish, they convey the essence of the works themselves.

In Saura's Tango, the extreme colour saturation and silhouette effects contribute to the general mirroring undertaken in the film. Saura is very keen on the transmission of the mood through colourful ambiances and the textural impression of inscribing the dancers' bodies against the background or fashioning them with light. For example, at one point, the renowned artist Juan Carlos Copes, who plays the diegetic choreographer, is rehearsing with part of the dance troupe to the sound of piano and bandonéon. He starts to show some routine steps to the dancers in absolute darkness, despite the fact that they cannot see him properly, but allowing for a grandiose silhouette effect for the film viewers. In his film, Saura's use of large panels (panós) that can be illuminated from the front or the rear and have their colour and brightness manipulated in the middle

10 This intricacy of the dance stems from the constant improvisation, which requires maximum attention to one's partner actions and an extremely quick deductive reasoning in order to react accordingly (Olszewski 2008, 69-72; Thompson 2005, 293). 
of a shot by employing theatrical dimmers is the main self-reflexive tool, to which all the strategies revealing the filmic apparatus are anchored. To begin with, they work as screens upon which metaphorical films as well as some real ones can be projected. ${ }^{11}$ Every time the dancers interact in front of these panels, they can be said to be enframed and tango becomes the object of the image twice, in the dancers themselves moving to the music and in the general subject being portrayed. Since many scenes in Saura's film are dancing, singing and performing rehearsals taking place in such a framed environment, they can be considered hermetic unities operating as films within the film. These are an important tool for glamourizing tango in Saura's film. ${ }^{12}$ For example, staff members working in the lighting and set design (gaffers and prop people), who are seen transporting ladders, panels and so on, are not colourfully lighted or framed against the panels as tango musicians or dancers are. [Fig. 1.]

Because of their framed nature and similar ability to section space, mirrors are often used to encase dancers in Saura's film, with the added advantage that they relay reflexes, multiplying the image in manifold ways, extending the invisible into the visible (i.e. into the frame) and vice versa. This device is particularly effective in the musical number Tango del atardecer (composed by Lalo Schifrin) in which the two female lead dancers, Laura and Elena, figuratively fight for one of the leading men [00:54:00 - 00:57:40]. In this scene, the three walls of the dance studio are panelled with top-to-bottom mirrors reflecting the actors standing up as well as the company dancers sitting on the floor and watching the leads rehearse. The remaining side of the studio, corresponding to the theatrical fourth wall, features a camera mounted on a crane, which is also reflected on the back, opposite, wall. The overall colour is saturated green, the very colour of jealousy, ${ }^{13}$ the passion that the choreography of this particular dance depicts. [Fig. 2.]

The total coincidence of two films (intra- and extradiegetic), directed by two different filmmakers (the fictional Mario/Sally and the real Saura/Potter), is what Metz (1966) considers to be a perfect mise en abyme, the point at which two narratives/processes become one, reflecting one another. In Dällenbach's terminology (1977) this corresponds to the most complex variety of fictional mise en abyme, which he calls "aporetic." The word is quite apt since such a device

11 For example, an excerpt of the film Tango! (1933, directed by Luís Moglia Barth) and another one with Carlos Gardel singing.

12 The same strategy is applied to both danced and instrumental musical pieces.

13 Hence the expression "the green-eyed-monster." In English, green is also the colour of envy ("green with envy"). 
is based on a double conundrum: the film reflects both ways (from the insideout of the fiction, and from the outside-in of the extra-diegetic procedures of the director), engendering impossibilities. The end of Tango is by far the best evidence of this. Throughout the film we are led to think that the supposed mobster, Angelo Larroca, has a violent temper and is quite capable of vengeance. When everything seems to be heading for disaster, typical of tango plots, where usually drama is an outcome of jealousy, there is no murder. Instead, the mobster laughs and asks: "Have I been convincing?" Someone else replies: "Let's see what the director has to say." Have we been watching a fiction all along?

Saura's film casts that doubt from the very beginning. Following the opening credits, which start in a lateral pan of the Río de la Plata docks and end inside an apartment, "Mario," the diegetic director, is seen reading a screenplay illustrated with storyboard vignettes, entitled Tango. The document describes the credits we have just watched and the interior of the apartment in which the pan ended and introduces the protagonist, the intra-diegetic Mario Suarez, ending with the statement: "Mario is pensive" (upon which "Mario," Saura's protagonist, does become pensive). [Figs. 3-4.]

The film conducts a ruse all along and by the climactic end the film's viewers feel they have been attending the realization of Saura's Tango film instead of Mario's work-in-progress project. In fact, the intertwining of these two artworks and realities is so masterfully accomplished that we seldom find the presence of cameras strange (in what seems to be merely preparatory work). In fact, it is not absolutely clear what kind of work is being done, since in the conversation with the main investor the word "film" is never pronounced; the set design, the lighting, the theatrical configuration of the space and the long shots point to a stage show, but the omnipresence of the camera, mounted on a crane, points to cinema instead. Whatever it is, it is very much under construction as the film viewers watch it. In a scene occurring one hour into the film, Mario is still reflecting on the narrative: "You need more discipline. What's the dramatic line that unifies all this?" Significantly, at the end of the scene, Mario looks straight at the camera, towards the film viewers.

In Potter's film, this cross-fertilization of reality and fiction, of art and life, attains its climax near the end, when the viewers realize that they have been watching the tango movie all along. In The Tango Lesson, after "Sally" has given up on her original film project, and while looking for a studio rental space in Buenos Aires, Pablo asks her: "What are we doing?" [if there's no money for the film yet]; to which Sally replies "We're doing it anyway." Diegetically, "Sally's" 
film is at a standstill, but in fact Potter's The Tango Lesson is evolving in front of us and reads like one of the most creative opuses on dance ever directed.

\section{Learning the Tango Chords}

Saura claims to have "entered the world of the musical film [because of his] obsession... to be able to fit the camera to the music. He wanted the camera to be one of the dancers" (Castro, in Willem 2003, 134). Although the idea to do a project on tango was not his to begin with, he embraced the challenge willingly (Ponga, in Willem 2003, 150). Saura's tango film is a chronicle of tango history as well as a compendium of tango styles, be they instrumental, danced, or sung, as much as it is a compendium on filmmaking (including the stages of conception and shooting). Very few scenes in Saura's Tango are devoid of intradiegetic music. The few that exist are, however, imbued with the spirit of tango culture and serve - via the narrative and the characters' interaction - as further explanations thereof. For instance, when Mario takes the young Elena to dinner they talk about women's beauty, men's dominance, vigour, desire and the will to live (all undertones of the tango philosophy).

Saura's Tango presents practically all possible variations of tango dance in Argentina: group dancing, solo performer, pairs of dancers, male duel [el tango del compadrón], trio and even the more recent queer tango (in this case an all-male collective number charged with a homoerotic feeling). There is even a choral tango ensemble à la Broadway about the period of the Argentinian military dictatorship (La Guerra Súcia, or "Dirty War") which is also part of the history of Argentina, and there is no Argentina without tango. ${ }^{14}$ As one character explains: "The torturers played tangos very loudly so that the cries of the tortured would not be heard." One dance in this sequence is accompanied by no music whatsoever. Abolishing the music in this way enables the cries of the tortured to symbolically come through. Additionally, this void reinforces the overall importance of music in the film, which features only one piece of music apart from tango: the operatic chorus "Va, pensiero" from Verdi's opera Nabucco, meant to represent the European immigrants' arrival in Argentina and their predominantly Italian (and Spanish) roots. The last section of the film, in which this operatic chorus is inserted, is staged as a dress rehearsal and strongly resembles the Hollywood musical "ballet sequence," for three reasons: it is longer

14 Even though this was the period when tango was less prominent in the country, for political reasons. 
than other musical sequences, is placed at the end of the film and is envisaged as a spectacular closure.

Sally Potter acknowledges her two decade-long wish to make a musical film, one that would reinvent the genre for the present and employ a different artistic language than the Hollywood musicals of the 1940s. However, as she confesses, throughout this period of time, she had absolutely no intention of making a film on tango (Béhar 1997). She ended up making a musical hybrid, just like Argentine tango itself increasingly incorporated - from the 1960s onwards - other musical influences, such as classical music, jazz, and electronic music. The protagonist Sally and the dancer Pablo always end up tangoing together, even when heavy rain constitutes a serious meteorological hindrance (Gene Kelly also danced under similar circumstances in Singin' in the Rain). The film evokes the tradition of classical Hollywood musicals, only to demystify it. The character Pablo Verón wishes to become a film star as renowned as Gene Kelly and performs some tap dancing in order to convey his point to Sally. The intertextual parallel established between Potter's The Tango Lesson and An American in Paris (Vincente Minnelli, 1951 - the quintessential musical film set in the French capital, where Potter's diegesis is also partially set), reinforces the influence of Hollywood musicals on her movie. Yet in Potter's film, which has a more cohesive narrative than Saura's - as it focuses on the sentimental attachment of the lead couple and their respective quests for identity -, the dances are not staged as downright musical numbers or made to appear in unrealistic settings portrayed in a stylized way. Quite the opposite. Potter's film, about the "true" Argentine tango, is mostly shot in black and white; only Sally's ultimately abandoned fashion film is seen in colour (as a product of her imagination). Glamour is, consequently, abandoned in favour of genuineness.

On a first apprehension of the title, the word "lesson" seems inappropriate to describe what is really going on in the film's structure. In fact, throughout the film "Sally" takes not one, but twelve tango lessons - singled out to the film's viewers by means of white titles upon a dark background. These so-called lessons, however, do not strictly coincide with scenes in which she is seen either learning or practicing tango; they also include other scenes where no dancing whatsoever takes place. Ultimately, the film teaches only one big lesson about tango, learned by the protagonist Sally and conveyed to us in song at the end: "You are me and I am you. / One is one and one are two." This is her recipe for the right amount of leading and following required by tango. Be neither a leader, nor a follower, but both - she indirectly claims. 
In reality, tango as a highly complex dance requires the follower, traditionally the woman, to be extremely technical in order to be able to accompany the leader, usually the man. She needs to be able to walk backwards with her eyes closed and to react to her partner's hand and body pressures (a subtle gesture known in tango language as la marca). One of Tango's choreographers, Juan Carlos Copes himself, once said: "La marca is part of the shared intimacy of tango, 'not she and I but us"' (quoted in Thompson 2005, 279). Brandon Olszewski, a male tango instructor in the United States, claims that this intimacy between the two partners is where the fascination as well as the creativity of tango resides. This places both dancers on equal footing, so to speak. "Unlike ballroom dance this ambiguity promotes a somewhat egalitarian relationship between leader and follower [...] and also contributes to excitement and expressiveness of the dance" (Olszewski 2008, 70). In his opinion, "Good dances are connected dances, and connected dances have not two dancers, but one dancer with four legs" (2008, 68). Upon careful observation, it seems more difficult to follow than to lead, so it would perhaps be appropriate for leaders to express their leading powers with modesty. In Potter's The Tango Lesson, the symbolic melody mentioned in the previous paragraph is played only after Pablo - Sally's teacher and dancing partner, the real-life tango dancer Pablo Verón - accepts her role as the leader of the technical crew in the making of the film, which makes him a follower of her directorial cues. Hence, the tango sung by Sally comes to exist in plenitude.

Although, as previously mentioned, Saura stated that he wanted to make the camera dance, it is Potter who best achieves this goal, something she also voices in an interview: "I wanted the camera to dance, I wanted it to do everything it can do in a normal film: dive, duck, go behind, go in front, up, down, around, move intimately as part of the thing, not just a point of view on it” (Béhar 1997). On dancing interludes, she opts for medium shots, slightly wider than Saura's, framing half of the dancers' legs or their full legs at once and not just their feet, thus conveying the leg work technique more fully and allowing for the perception of the steps, in a textbook manner. Notwithstanding this, the camera in The Tango Lesson circles and flutters around the dancers, following them in walks across the various dance floors featured in the film, a process which is indisputably linked to the music. In fact, during the dance practice with Pablo Verón in lesson number nine, the pair is having trouble connecting their steps and dancing as one until the professional dancer turns on the tape recorder in his apartment. The instrumental part of the song called Pensàlo bien - with music by Juan D'Arienzo, one of the composers most featured in Potter's film - is heard. Instantly, they get into synch. 
To prove that Sally and Pablo make a good dance pair, Potter jumps from scene to scene using musical sound bridges, in which the dance flows in musical continuity despite the change in settings and contexts. As if the pair was dancing across time and space, in perfect motion but frozen in the moment, their moment together in the tango universe. This coming together in dance finds its metaphorical climax towards the end of the film, during the performance of Ástor Piazzolla's Libertango in an empty dance hall. Sally dances with Pablo Verón, but also with Gustavo Naveira and Fabián Salas, two Buenos Aires tango instructors, who are playing themselves in the film, and from whom she took some of the lessons. The foursome walk, turn and spin to the music at a high tempo, improvising frantically in a cry of freedom. ${ }^{15}$ The jumpy, strong notes of the bandonéon, accompanied by rhythmic percussion in staccato, highlight the dancer's flexing torso and legs. The scene, representing the happy outcome of Sally's quest for identity and all her tango lessons, contrasts with a previous dance in which she performed publicly in a theatre with Pablo Verón, to the famous notes of La Yumba (by Osvaldo Pugliese, 1946), but in which they were not moving as one.

\section{Conclusion: In closing, or cadenza final}

Ultimately, both Saura's and Potter's films can be interpreted as full-blown metacinematic musicals, although the former is stagier and seems to have more music in it than the latter. In fact, the difference is insignificant: there are twenty-one tangos in Saura's film and seventeen in Potter's. ${ }^{16}$ If, apparently, they rewrite the Hollywood musical tradition under the guise of the art-house film (auteur film), they do it not to dwell on a film genre, but rather on an art genre: tango. They do not honour music, dance and song in general; they specifically pay tribute to tango and its culture. If Hollywood musicals are intertextually present, that is simply to reinforce the difference from escapist spectacle, which resembles much more the European variety of tango, characterized by the artificially rigid smiles of the dancers and their broad leg and arm movements. The films I presented in this article correspond broadly to what Jane Feuer calls "art musicals" (2001), based on the creation of a show or connected to artistic forms. They are, indeed, self-reflective as Feuer contends, and they seem to follow her three axioms for the genre (2001, 32): (1) there is always some "falsehood" involved, something that

15 In Spanish, Libertango is an agglutination of libertad (freedom) and tango.

16 Three tangos feature in both films: La cumparsita (music by Gerardo Matos Rodríguez and lyrics by Pascual Contursi, 1916), possibly the most famous tango ever; the aforementioned La Yumba (1946); and Quejas de bandonéon (Aníbal Troilo). 
does not correspond to reality; (2) these spectacles are imbued with "aura"; (3) there is an interchange between demystification and re-mystification. However, Saura and Potter do not aim to assign value to entertainment and its mythical status; quite the opposite. By choosing to make two tango musical metafilms that use mise en abyme to interrelate tango and life just as much as cinema and art - Saura and Potter reinforce the artistry of their own art and, in the meantime (and this is the real tour de force), its mythical value on par with the mythical value of tango itself.

Both tango films are unquestionably intermedial works, as already mentioned here, but where they excel and what makes them worthy of further analyses added to the already existing ones (e.g. Pieldner 2019), is the very nature of their hybridity. Seemingly, it could be argued that they are examples of Petr Szczepanik's intermedia reflexivity (2002) because reflexivity is their main cinematic strategy and formal outcome. Yet, Szczepanik's concept does not equate with each other the art forms involved in such an interrelation. He conceives of one as being superior to the other ("one media form takes over and transforms the structural components of another" 2002, 29) and reinforces the differences in "hybrid forms of images" (e.g. those of cinema and video in Jean-Luc Godard's films). Although in Saura's Tango and Potter's The Tango Lesson reflexivity operates at a representational level in a quite experimental fashion, these films are more sensorial and synaesthetic than Szczepanik considers: they are not simply a feast for the eyes, they are a feast for the sensorium. They are also reflexive on the level of the diegesis, but their reflexivity is not the product of a genre-bound formula, least of all fantasy, as the quoted commentator argues. This explains why I left the word intermediality out of the article's title.

In my comparison of tango to cinema and in Saura's and Potter's specific approach to these two arts forms, I do not perceive an in-betweenness or an intersenses, according to Dick Higgins's concept of intermedia (1965/1981). Tango and reflexive cinema are hybrid forms in themselves, being brought together to generate further hybridity. They are different, in that they retain their qualities; but also alike, in that they mutually benefit from their symbiotic relationship. They do not mix to the point of fusion, or else they would be examples of screendance, as I argue elsewhere in relation to Saura's "pure musicals" (as he terms his so-called documentaries from Sevillanas [1992] onwards (Chinita, 2021, forthcoming). The camera does not only dance with the dancers, but decomposes and (re)assembles their movements; it lays the ground upon which they dance, a narrative ground. Consequently, music/dance/singing are cinema's triplets and their mirroring is 
what these two films are really about. When all is said and done, these films are remembered not merely because of their cinematic artistry, but because tango shines through and makes them memorable. They are truly imbued with aura, an aura which depends entirely on the association of these two art forms/cultures.

\section{References}

Béhar, Henri. 1997. Sally Potter on The Tango Lesson. Film Scouts. http://www.filmscouts.com/scripts/interview.cfm?File=sal-pot. Last accessed 05. 10. 2014.

Borges, Jorge Luis. 2018. O Tango: Quatro Conferências. [Tango: Four Conferences], Lisbon: Quetzal Editores.

Cámara de Landa, Enrique. 2003. Il tango argentino. In 59 $9^{\underline{a}}$ Settimana Musicale Senese (Fondazione Accademia Musicale Chigiana), 95-107. Siena: Monte Dei Paschi di Siena.

Castro, Antonio. 2003. Interview: Carlos Saura (1996). In Carlos Saura: Interviews, ed. Linda M. Willem, 52-64. Jackson: University Press of Mississippi.

Chinita, Fátima. Dance and the Mediated Immersive Flux in Carlos Saura's Musical Hybrids with Live Feed. In The Intermediality of the Screen: Mediation, Performance, Immersion, eds. Ian Robinson and Shana MacDonald. Forthcoming.

Dāllenbach, Lucien. 1977. Le Récit spéculaire. Essai sur la mise en abyme [The Mirror in the Text]. Paris: Éditions du Seuil.

Davis, Kathy. 2015. Should a Feminist Dance Tango? Some Reflections on the Experience and Politics of Passion. Feminist Theory vol. 16, no. 1 (March): 3-21.

De Baecque, Antoine. 2003. La Cinéphilie, invention d'un regard, histoire d'une culture, 1944-1968. Paris: Arthème Fayard.

Elsaesser, Thomas. 2005. Cinephilia or the Uses of Disenchantment. In Cinephilia: Movies, Love and Memory, eds. Marijke de Valck and Malte Hegener, 27-43. Amsterdam: Amsterdam University Press.

Feuer, Jane. 2001. The Self-Reflective Musical and the Myth of Entertainment. In Hollywood Musicals, the Film Reader, ed. Steve Cohan, 31-40. London and New York: Routledge.

García Brunelli, Omar. 2015. Los estudios sobre tango observados desde la musicología. Historia, música, letra y baile. [Tango Studies from the Perspective of Musicology. History, Music, Literature and Dance], El oído pensante [The 
Ear That Thinks] vol. 3, no. 2: 1-32. http://ppct.caicyt.gov.ar/index.php/ oidopensante. Last accessed 22. 02. 2020.

Grunes, Dennis. 2007. The Tango Lesson (Sally Potter, 1997).

http://grunes.wordpress.com/2007/06/16/the-tango-lesson-sally-potter-1997. Last accessed 05. 10. 2014.

Higgins, Dick. 1965/1981. Synesthesia and Intersenses: Intermedia. Audiovisual e Multimédia II. https://am2intermedia.wordpress.com/intermedia/. Last accessed 26. 12. 2020.

Horn, David et al. (eds). 2014. Tango. In Bloomsbury Encyclopedia of Popular Music of the World. Vol. IX - Genres: Caribbean and Latin America, eds. David Horn and John Shepherd, 826-843. London et al: Bloomsbury.

Link, Kacey and Kristin Wendland. 2016. Tracing Tangueros: Argentine Tango Instrumental Music. New York: Oxford University Press.

Ng, Jenna. 2005. Love in the Time of Transcultural Fusion: Cinephilia, Homage and Kill Bill. In Cinephilia: Movies, Love and Memory, eds. Marijke de Valck and Malte Hagener, 65-79. Amsterdam: Amsterdam University Press.

Metz, Christian. 1972. A Construção "em abismo" em Oito e Meio de Fellini, 1966. [The Mirroring Image Construction in Fellini's $8^{1 / 2}$ ]. In A Significação no Cinema [Film Language: A Semiotics of the Cinema], 217-224. São Paulo: Editora Perspectiva.

Metz, Christian. 1980 [1977] O Significante Imaginário: Psicanálise e Cinema [The Imaginary Signifier: Psychoanalysis and the Cinema], Lisboa: Livros Horizonte.

Metz, Christian. 1991. L'énonciation impersonnelle ou Le site du film. [Impersonal Enunciation, or the Place of Film], Paris: Méridiens Klincksieck.

Olszewski, Brandon. 2008. El Cuerpo del Baile: The Kinetic and Social Fundaments of Tango. Body and Society vol. 14, no. 2: 63-81.

Pfeffer, Murray. A Brief History of Tango. http://www.triogarufa.com/tangohistory.html. Last accessed 05. 10. 2014.

Pieldner, Judit. 2019. From Paragone to Symbiosis. Sensations of In-Betweenness in Sally Potter's The Tango Lesson. Acta Universitatis Sapientiae, Film and Media Studies, vol. 17: 23-44.

Ponga, Paula. 2003. Tango according to Saura (1998). In Carlos Saura: Interviews, ed. Linda Willem, 150-155. Jackson: University Press of Mississippi.

Siska, William C. 1979. Metacinema: A Modern Necessity. Literature/Film Quarterly vol. 7: 285-289. 
Szczepanik, Petr. 2002. Intermediality and (Inter)media Reflexivity in Contemporary Cinema. Convergence vol. 8, no. 4: 29-36.

Thompson, Kristin. 1977. The Concept of Cinematic Excess. Ciné-Tracts vol. 1, no. 2: 54-63.

Thompson, Robert Farris. 2005. Tango: The Art History of Love. New York: Vintage Books.

\section{List of Figures}

Figures 1-4. Carlos Saura's Tango.
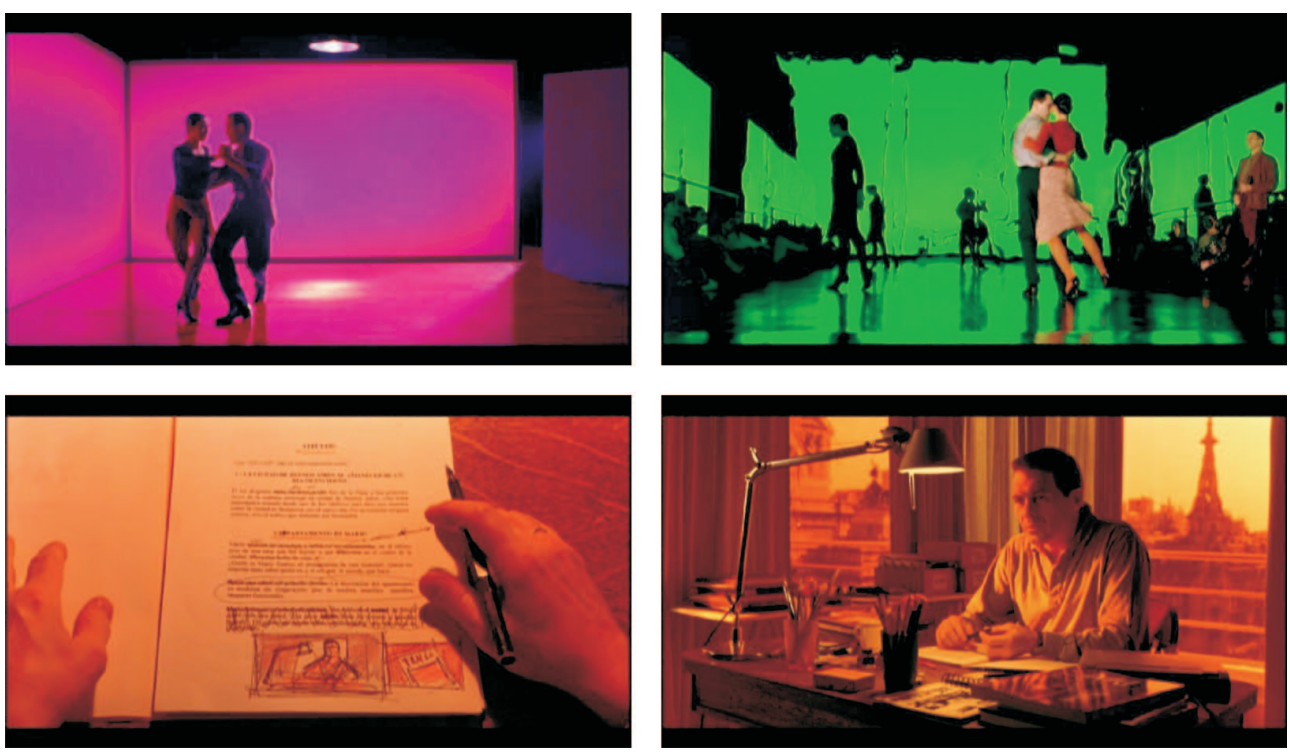